\title{
Quality and Intensity of the Tissue Response to Two Synthetic Granular Hydroxyapatite Implanted in Critical Defects of Rat Calvaria
}

Neusa Motta de Freitas Costa ${ }^{\mathrm{a}}$,Bruno Raposo Melo ${ }^{\mathrm{b}}$, Rosana Tavares Brito ${ }^{\mathrm{b}}$,

Gustavo Vicentis de Oliveira Fernandes ${ }^{\mathrm{b}}$, Vagner Gonçalves Bernardo ${ }^{\mathrm{b}}$, Eliene Carvalho Fonseca ${ }^{\mathrm{c}}$,

Marcio Baltazar Conz", Glória Almeida Soares ${ }^{\mathrm{a} *}$, José Mauro Granjeiro $^{\mathrm{b} *}$

${ }^{\mathrm{a} C O P P E}$ and Polytechnic School, Federal University of Rio de Janeiro - UFRJ, P.O. Box 68505, 21941-972 Rio de Janeiro - RJ, Brazil

${ }^{\mathrm{b}}$ Department of Cell and Molecular Biology and Cell Therapy Center, Antonio Pedro University Hospital - HUAP, Fluminense Federal University - UFF, 24020-150 Niterói - RJ, Brazil

'Department of Pathology, Antonio Pedro University Hospital - HUAP,

Fluminense Federal University - UFF,

24033-900 Niterói - RJ, Brazil

Received: September 29, 2008; Revised: March 23, 2009

\begin{abstract}
The objective of the present study was to evaluate the quality and intensity of the tissue response to two synthetic hydroxyapatites implanted in critical defects in the skulls of rats. Sixty animals were divided into three experimental groups: I (control), II (HA-1 = HA with $28 \%$ crystallinity) and III (HA-2 = HA with $70 \%$ crystallinity). They were sacrificed $1,3,6$, and 9 months after implantation $(\mathrm{n}=5$ individuals per group/period). Histomorphometric analysis included i) counting of polymorphonuclear leucocytes, mast cells, macrophages and foreign body multinucleated giant cells stained with anti-lysozyme; ii) microvascular density stained with anti-Factor VIII and iii) degree of cell proliferation stained with anti-PCNA. There were no significant differences between the experimental groups in either the quality or quantity of cells in the inflammatory infiltrate, or the degree of angiogenesis and cell proliferation. We conclude that HA-1 and HA-2 are biocompatible and that the physico-chemical differences of these biomaterials did not affect cellular response.
\end{abstract}

Keywords: hydroxyapatite, histomorphometry, bone repair, immunohistochemistry

\section{Introduction}

Nowadays, several different materials are clinically employed on both functional and esthetic rehabilitation ${ }^{1-4}$. Prominent among the alloplastic materials used on bone surgery are calcium phosphates, specially hydroxyapatite (HA), which displays variable physicochemical and morphologic properties such as crystallinity, solubility, size and shape of pores, granulometric distribution, to mention a few. The controlled production of synthetic bone materials with selected physicochemical characteristics, as compared to the use of autogeneic grafts, eliminates the need for a second surgical site, thus reducing surgical time and morbidity. It also increases patient safety by eliminating the potential for disease transmission.

Solubility properties of biomaterials are closely related to biocompatibility and chemical reactions to other compounds. The solubility rate of hydroxyapatite depends on differences in $\mathrm{Ca} / \mathrm{P}$ ratio, porosity, crystal size, and crystallinity ${ }^{5}$. Particularly, poor crystalline HAs are more soluble than sintered highly crystalline $\mathrm{HAs}^{6}$. Biological dissolution of these materials releases local concentrations of divalent ions, which may influence mineralization ${ }^{7}$. Therefore, hydroxyapatites with high crystallinity are chemically more stable ${ }^{8}$ and interfere with cell proliferation by decreasing in vitro cell adhesion ${ }^{9,10}$. A previous study from our group ${ }^{11}$ showed, however, that new bone formation occurs at very similar levels on critical defects from rat calvaria in contact with HAs of extremely different crystallinity levels, corroborating evidences from other studies in the literature ${ }^{12,13}$.

Despite advances in the development of biomaterials, there are still gaps in the understanding of the biologic response to implanted materials. It is well known, however, that once the biomaterial is introduced into the body, a sequence of events takes place in the surrounding tissues, which may culminate with the formation of foreign body giant cells and a fibrous capsule $\mathrm{e}^{14-17}$.

Blood coagulation starts the inflammatory stage of wound healing and the diffusion of chemoattractants (growth factors from platelets) attracts polymorphonuclear neutrophils (PMN), followed by monocytes from blood. In parallel to cell migration and proliferation, cells (fibroblasts) synthesize extracellular matrix (ECM) proteins depositing them from the margin of the wound inward. PMN and macrophages characterize respectively the acute and chronic phases of inflammation. Histamine and heparin, released from mastocytes, both control key events in the inflammatory response to implanted biomaterials, as well as the foreign body reaction intensity by mastocyte-derived interleukins ${ }^{18}$. The chronic phase is established by migration of monocytes and accumulation of plasma cells, lymphocytes and macrophages, being the

*e-mail: gloria@metalmat.ufrj.br, jmgranjeiro@vm.uff.br 
latter an essential component to the transition from the inflammatory to the proliferative stage of wound healing. The wound healing response to implanted biomaterials exhibits a foreign body reaction, formation of granulation tissue and angiogenesis from proliferating endothelial cells ${ }^{19,20}$. Particularly for bone grafts, angiogenesis plays a pivotal role in osteogenesis and osseointegration, by delivering pericytes which are able to differentiate in osteoblasts ${ }^{21}$.

The chemical properties of the surface of the biomaterial may change the behavior of macrophages in processes such as adhesion, apoptosis, fusion and cytokine secretion ${ }^{22}$. However, until now, there is no data about the prevailing cells involved in the tissue response to HA with different cristallinity. This information would be useful to improve the knowledge of the mechanism of bone formation and to direct the development of new biomaterials. Therefore, the objective of the present study was to evaluate the quality and intensity of the tissue response to two synthetic hydroxyapatites with different physical and chemical properties implanted in critical defects in the skulls of rats, contributing to better understand the tissue response to hydroxyapatite.

\section{Materials and Methods}

\subsection{Production of granular hydroxyapatite}

Different hydroxyapatite powders were synthesized by a wet method and granules were produced by pressing and calcination, resulting in two distinct products for implantation ${ }^{11}$. Briefly, two powders of hydroxyapatite with $\mathrm{Ca} / \mathrm{P}$ molar ratio of 1.60 and 1.67 (HA-1 and HA-2, respectively) were synthesized by Brazilian Center for Physics Research (CBPF). Discs of hydroxyapatite were produced from each powder by uniaxial compression using a steel matrix followed by heat treatment, in order to remove the porogenic agent and increase mechanical strength. The discs were crushed and classified to obtain granules in the range between 250 and 1,000 $\mu \mathrm{m}$. The granules were washed, dried and sterilized using gamma radiation ${ }^{11}$.

\subsection{Animals and implantation procedure}

All procedures followed the guidelines of the Brazilian College of Animal Experimentation (COBEA), and were approved by the animal research ethics committee of the School of Dentistry of Bauru (USP, CEEPA ref. 18/2004). Briefly, sixty male five-month-old Wistar rats (Rattus norvegicus), weighing about $350 \mathrm{~g}$, were randomly divided into three groups of 20 each: (I) control, (II) HA-1 and (III) HA-2 respectively. Five animals of each group were sacrificed at 1, 3, 6 and 9 months respectively after the surgical procedure. Tricotomy and incision were performed at the frontal-parietal region of each rat under general intramuscular anesthesia with xilazane 2\% (Rompun, Bayer-S.A, São Paulo, SP, Brazil) and ketamine 5\% (Ketalar, Achë S.A, Butantã, SP, Brazil), in a 1:1 proportion. A perforation throughout the whole thickness of the diploe was performed with an $8.5 \mathrm{~mm}$ external diameter surgical trephine and continuous irrigation with saline solution. At the respective experimental periods the rats were killed with anesthetic overdose, their skulls were removed and fixed in $10 \%$ buffered formaldehyde during one week. The specimens were then demineralized in a solution of EDTA (Merck, Germany) pH 7.2 for a period of approximately four months with weekly solution exchanges and processed for paraffin embedding.

\subsection{Microscopic analysis}

\subsubsection{Descriptive microscopic examination - hematoxylin and eosin (H\&E)}

Photomicrographs were made from the histological sections stained with hematoxylin and eosin using a Sony ${ }^{\circledR}$ Cyber-shot $\mathrm{P} 93$ digital camera in manual mode, $3 \times$ zoom, at 2,592 x 1,944 pixels, mounted on a Jenaval Zeiss trinocular optic microscope with a $100 x$ objective. In each section obtained from each animal approximately 40 non-overlapping fields were photographed, for a total of 2,364 digital images. In these images the presence of inflammatory cells such as polymorphonuclear leucocytes, mast cells and foreign body giant cells was assessed.

\subsubsection{Descriptive microscopic examination - immunohistochemistry}

Semi-serial $5 \mu \mathrm{m}$ thick sections were obtained from the paraffin blocks and processed. Briefly, paraffin sections were submitted to deparaffinization in xylene, followed by rehydration in decreasing alcohol solutions, ion blocking in $2 \%$ borax and endogenous peroxidase blocking with a $3 \% \mathrm{H}_{2} \mathrm{O}_{2}$ solution in PBS for 15 minutes. Antigen retrieval was achieved in phosphate-citrate buffer ( $\mathrm{pH}$ 6.0) for anti-lysozyme and anti-factor VIII only. BSA+ free-fat milk for 15 minutes blocked unspecific antigens for all antibodies used. Primary antibodies were diluted by 1:400 (anti-PCNA: \#JM3350R-100, MBL International, Woburn, MA, USA), 1:600 (anti-lysozyme: \#A0099, Dako Denmark ${ }^{\circledR}$ ) or 1:400 (anti-Factor VIII: \#A0082, Dako Denmark ${ }^{\circledR}$ ) and incubated with the histological sections for 30 minutes. Afterwards, sections for PCNA immunostaining were incubated with LSAB+ System-HRP kit (\#K0690, Dako Denmark ${ }^{\circledR}$ ), and lysozyme and factor VIII with Envision+ System-HRP (\#K4003, Dako Denmark $\left.{ }^{\circledR}\right)$, followed by staining with a chromogen solution (3,3’-Diaminobenzidine-K3468, Dako Denmark ${ }^{\circledR}$ ) for 3 minutes. Finally, the slides were counterstained with Harris's haematoxylin and mounted. All rinses were performed three times in $0.1 \%$ PBS/ Triton-X. Antibodies were diluted in $0.1 \%$ PBS/BSA. Negative controls were performed replacing the primaries antibodies for the same PBS/BSA solution.

The temporo-spacial distribution of immunopositive macrophages was determined with anti-lysozyme, the microvascular density was determined with anti-Factor VIII, and cell proliferation was identified and measured with anti-PCNA. The anti-lysozyme and anti-Factor VIII images were captured with a Canon ${ }^{\circledR}$ PowerShot A95 digital camera in automatic mode, 3.0 zoom at 2,502 x 1,944 pixels, mounted on a trinocular optic Jenaval Zeiss ${ }^{\circledR}$ trinocular optic microscope using a 40x objective. In each section from each experimental animal, 10 randomly selected, non-overlapping fields were photographed, for a total of 1,200 digital images. The sections immunostained with anti-PCNA were photographed with an Evolution ${ }^{\mathrm{TM}}$ MP video camera (Media Cybernetics, Bethesda, MD, USA) mounted on a Nikon ${ }^{\circledR}$ Eclipse E400 optical microscope using a 20x objective. In each section from each animal 10 randomly selected, non-overlapping fields were recorded for a total of 600 digital images.

\subsection{Histomorphometric analysis}

The histomorphometric analysis was accomplished with an Image Pro Plus ${ }^{\circledR}$ system (Media Cybernetics). In the H\&E sections, the cell counts were performed manually. In the sections stained for lysozyme/ Factor VIII all cells positive for lysozyme were counted, the macrophages being also identified by their morphology, and the microvascular density was evaluated, with the aid of a grid, by counting only vessels positive for Factor VIII with an internal diameter of less than $50 \mu \mathrm{m}$. In the PCNA sections, the area $\left(\mathrm{mm}^{2}\right)$ occupied by proliferating cells was measured and normalized by the total area of the connective tissue in each section.

\subsection{Statistical analysis}

The data analysis was performed by comparison of the means within each of the groups, namely Control, HA-1 and HA-2, and within each experimental time period (1, 3, 6 and 9 months). KruskalWallis tests, complemented with the tests of Dunn and Mann-Whitney, were used to determine significance at $\mathrm{p}<0.05$, since the differences among the standard deviations were extremely significant. 


\section{Results}

\subsection{Descriptive histological analysis}

\subsubsection{One month}

In the control group, the inflammatory infiltrate was typical of the chronic phase, with only a few polymorphonuclear leucocytes near the blood vessels (Figure 1a). The predominant inflammatory cells were mononuclear, suggestive of macrophages (Figure 1b). There were, however, cells suggestive of mastocytes scattered throughout the connective tissue (Figure 1c). The distribution of microvessels was homogeneous throughout the connective tissue (Figure 1d). The cellular proliferation was discrete and scattered in the connective tissue, suggestive of inflammatory cells and fibroblasts (Figure 1e).

In groups II and III (with granular HA), the distribution of polymorphonuclear cells and mast cells was similar to that in the control group. The macrophages were more abundant around the biomaterial. Multinucleated foreign body giant cells were found around the HA granules suggesting an attempt to absorption (Figure 1f). The distribution of microvessels was homogeneous. The proliferating cells were close to the biomaterial, being suggestive of inflammatory cells.

\subsubsection{Three months}

In the control group there was a reduction in the inflammatory infiltrate, particularly in the number of macrophages. Microvessels were similar to the previous period, but cell proliferation was more accentuated. In group II, the tissue around the biomaterial was similar to that in the previous period but angiogenesis was more intense than in the control group. Group III presented a larger number of macrophages than groups I and II.

\subsubsection{Six months}

In control group, the inflammatory mononuclear infiltrate and cell proliferation was less pronounced than in the previous period, but angiogenesis persisted. Groups II and III revealed a microscopic appearance similar to that of the previous period, with mast cells scattered through the connective tissue.

\subsubsection{Nine months}

In the control group, mononuclear inflammatory infiltrate and cell proliferation were discrete, with fewer macrophages than in one month samples. Similar features were observed in groups II and III.

\subsubsection{Histomorphometric analysis}

The concentration of polymorphonuclear cells (Figure 2a) and mast cells (Figure $2 b$ ) showed no statistically significant difference ( $p>0.05$ ) between the groups in any of the periods, but the number of mast cells evidently denote a decrease throughout the experimental period. Macrophages were the most abundant counted cells one month after implantation, and decreased significantly $(\mathrm{p}<0.05)$ in the next period except for HA-2 ( $p<0.01)$, which promoted the opposite effect (Figure 2c). Despite the fact that the absolute value of macrophages $/ \mathrm{mm}^{2}$ in the HA-2 group was 4.7 times greater than in the HA-1 group after 3 months, the p value was 0.077 .

The control group did not show multinucleated foreign body giant cells (Figure 2d), and there was no significant difference ( $p>0.05)$ in their numbers between HA-1 and HA-2 (Figure 3) during the studied periods.

Counting vessels with an inner diameter of less than $50 \mu \mathrm{m}$ (Figure 4) allowed determining the decrease in the microvascular density (Figure 2e, p < 0.05) between 1 and 9 months in HA-2.
Microvascular density increased $(\mathrm{p}<0.05)$ in HA-1 as compared to control group at 3 months. No significant changes in microvascular density occurred in the control group.

The number of proliferating cells predominated in the third month for control group, decreasing afterwards ( $p<0.05$, Figure $2 f$ ). In the HA groups, proliferating cells predominates in the first and second experimental periods, decreasing in the subsequent periods, but without significant differences $(\mathrm{p}>0.05)$ within groups.

\section{Discussion}

Since the beginning of $20^{\text {th }}$ century biomaterials have been intensely used to replace and augment damaged tissues ${ }^{23}$. Improving the knowledge on bone structure and biology in response to implanted materials have led to the development of new bioactive materials ${ }^{24}$.

In this study we showed for the first time that, when comparing the tissue response to hydroxyapatites with cristallinity of 28 and $70 \%$ (HA-1 and HA-2, respectively), no changes occurred in the kind or number of inflammatory cells recruited in response to its implantation in critical size bone defect.

Both HA-1 and HA-2 are biocompatible, since they did not damage the host tissue and allow the apposition of new bone near defect borders, in direct contact to their surfaces. The presence of hydroxyapatite granules in the scar tissue is also indicative of their participation in bone repair, as these remaining biomaterials become part of the bone mass of the grafted region ${ }^{25}$.

The defect produced in this animal model served as a "critical size defect" (i.e., a defect with the diameter at which regeneration does not occur). In no control-group animal the defect was completely filled with bone, as has been reported elsewhere ${ }^{26,27}$. The control group (negative control) showed only an inflammatory reaction resulting from the surgical procedure ${ }^{22}$ and the usual repair processes of injured bone, without increase in microvascular density nor significantly different cell proliferation when compared with groups HA-1 and HA-2. This is consistent with tissue reaction and cicatrisation induced by bone defects, as previously described ${ }^{28}$. Rare polymorphonuclear cells were found but almost exclusively near the blood vessels from which they came, and not around bone or biomaterials, and rarely dispersed throughout the connective tissue. The number of PMN cells also tended to decrease with time.

Mast cells, mediators of the inflammatory response to biomaterials, contribute significantly to the extent and degree of foreign body reaction, because they play an important role in the recruitment of phagocytes to the biomaterial implantation site, including macrophag$\mathrm{es}^{29}$. In this study, scattered mast cells were found in the connective tissue of all three experimental groups, and their presence decreased with time, indicating that the presence of these biomaterials, as well as their crystallinity differences, did not affect host response.

Fast degradable calcium phosphate ceramics are decomposed by macrophages and giant cells, while the slowly degradable ones are decomposed by osteoclast-type cells, in a process which may take months-years ${ }^{30}$. According to Kelly and Schneider ${ }^{31}$, both osteoclasts and foreign body multinucleated giant cells can be responsible for resorption. In the present work, macrophages were concentrated around the biomaterials and their disappearance along the experimental time intervals was associated with the increase of multinucleated giant cells, probably attempting to segregate and digest foreign materials. We were unable to determine in our study whether the multinucleated cells were osteoclasts, and no sign of HA degradation was observed, since particle-phagocytosis trough macrophages was not observed likewise. Macrophages and giant cells are able to phagocyte particles of around $10 \mu \mathrm{m}$, what may result in the accumulation of calcium in mitochondria and provoke cell death ${ }^{32}$. Macrophages in 


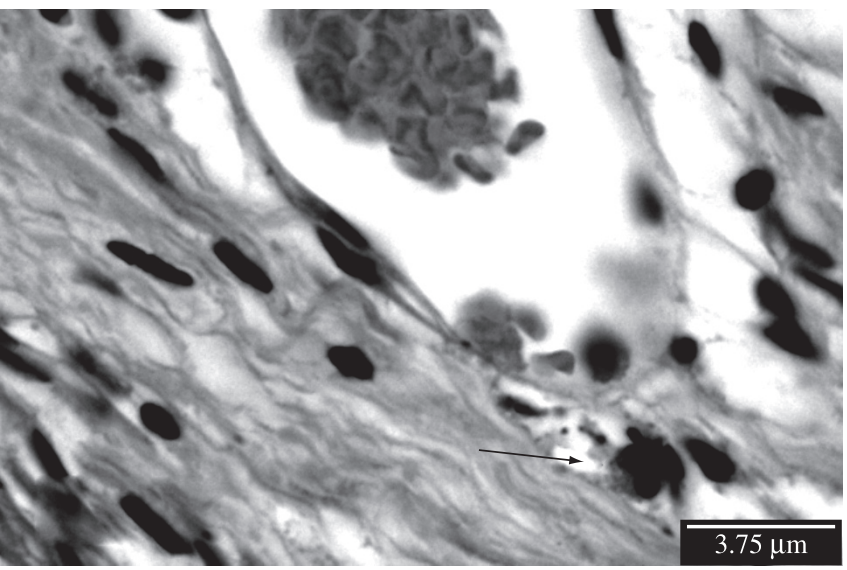

(a)

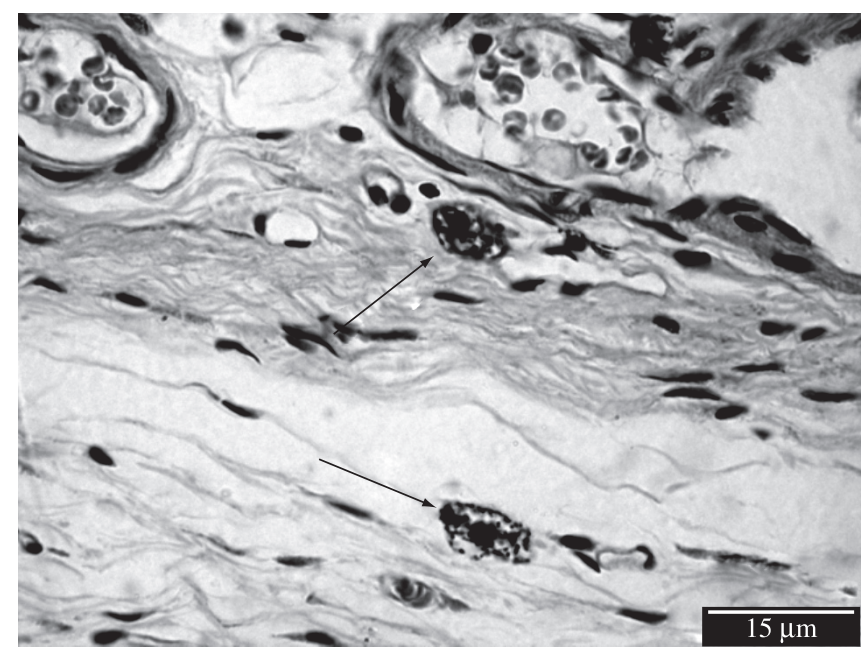

(c)

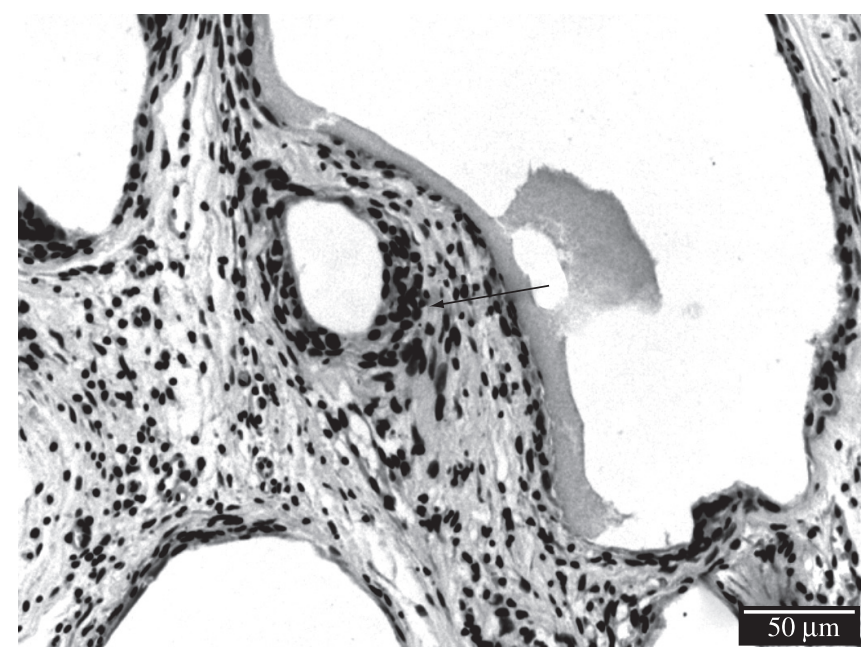

(e)

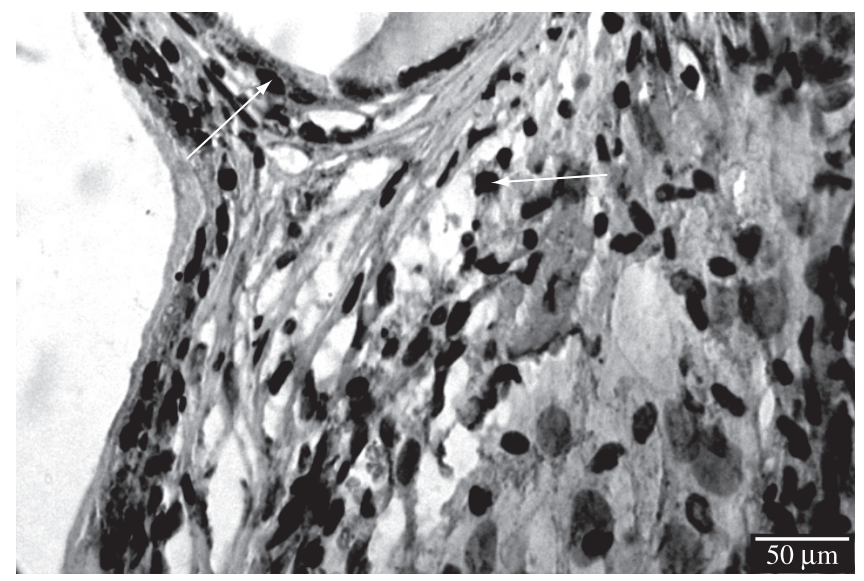

(b)

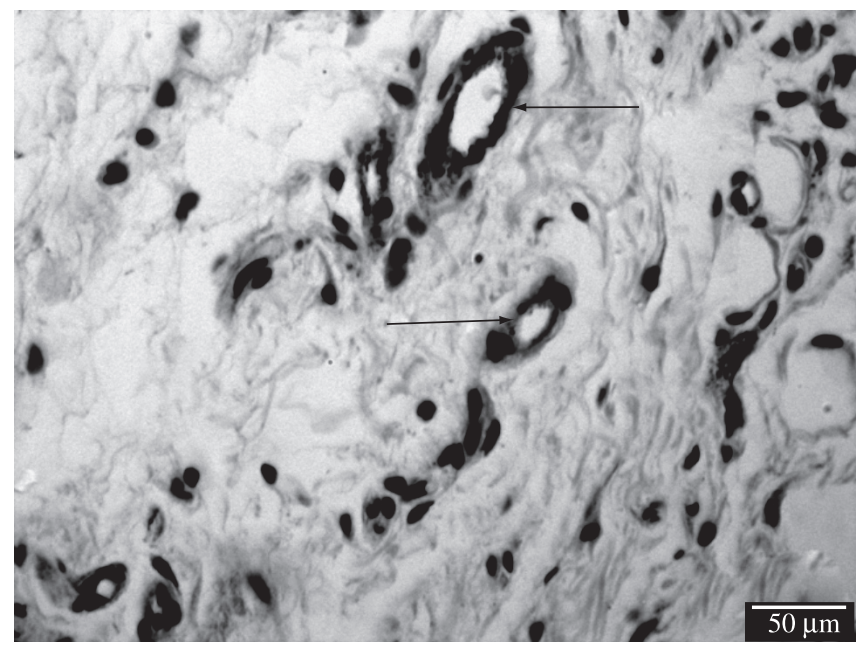

(d)

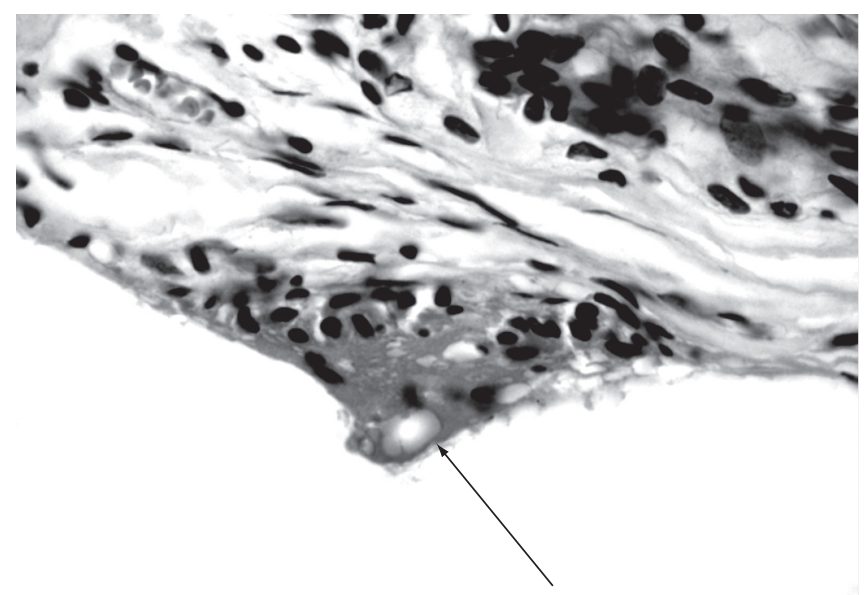

(f)

Figure 1. Photomicrographs of the tissue response after 1 month: a) Arrow on polymorphonuclear cell, H\&E, control group; b) Arrows on cells immunostained with anti-lysozyme = macrophages, group HA-1; c) Arrows on mast cells, H\&E, control group; d) Arrows on microvessels (anti-Factor VIII), group HA-1; e) Arrow on proliferating cells (anti-PCNA), group HA-2; and f) Arrow on multinucleated foreign body giant cell, H\&E, group HA-1. 


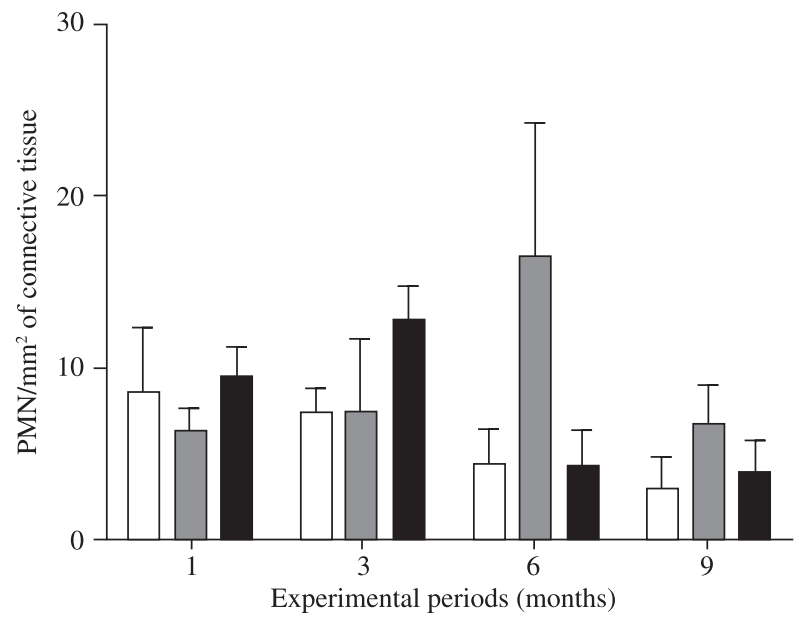

(a)

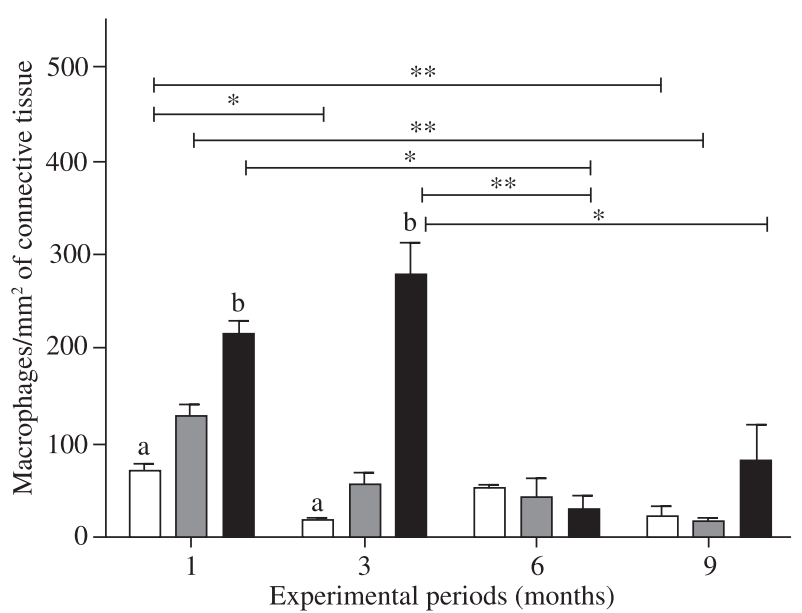

(c)

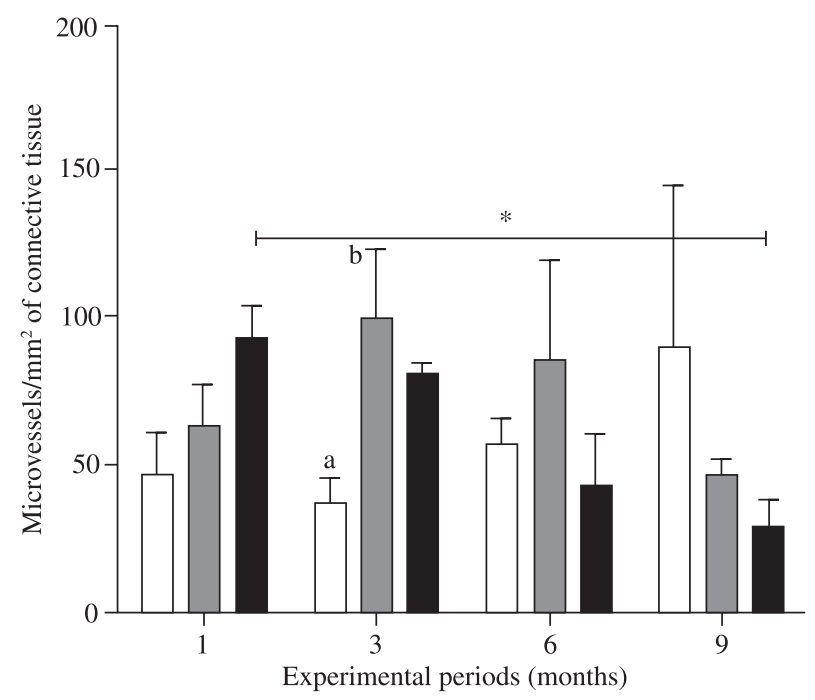

(e)

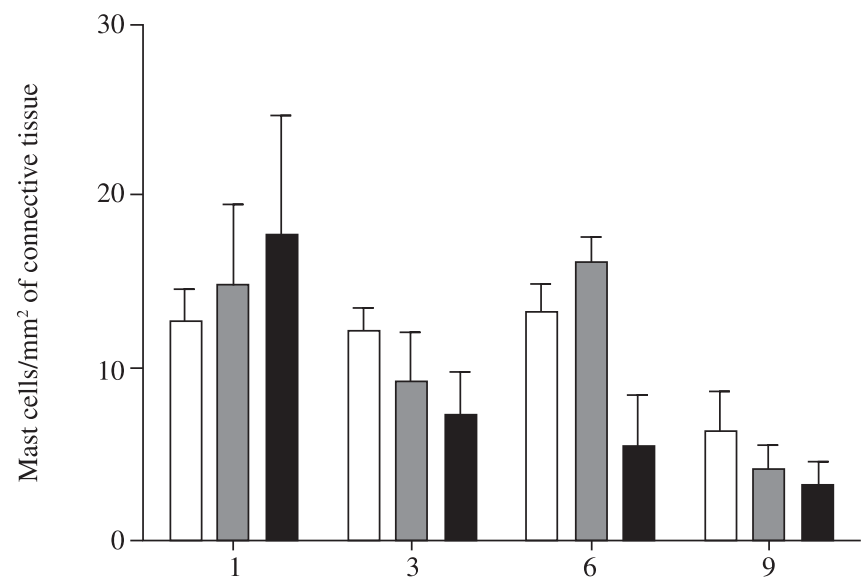

Experimental periods (months)

(b)

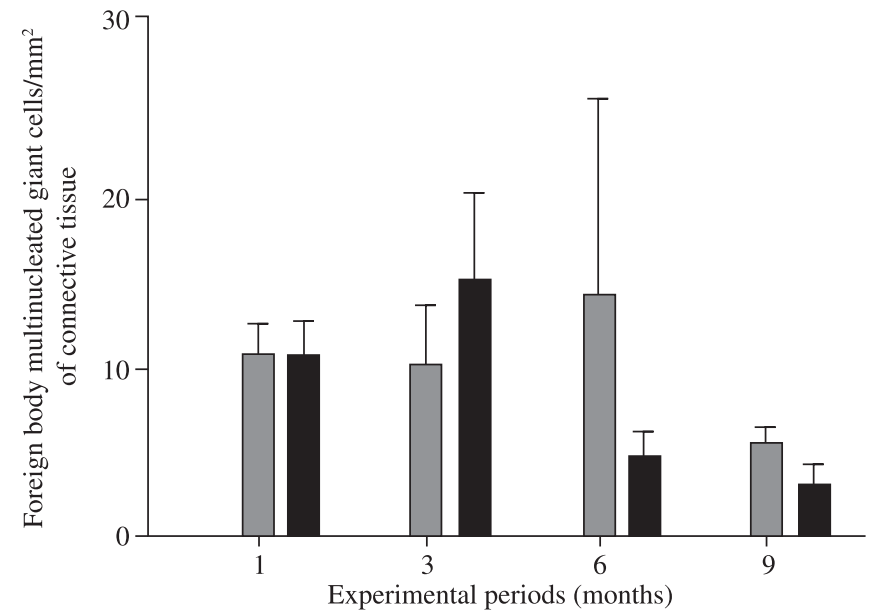

(d)

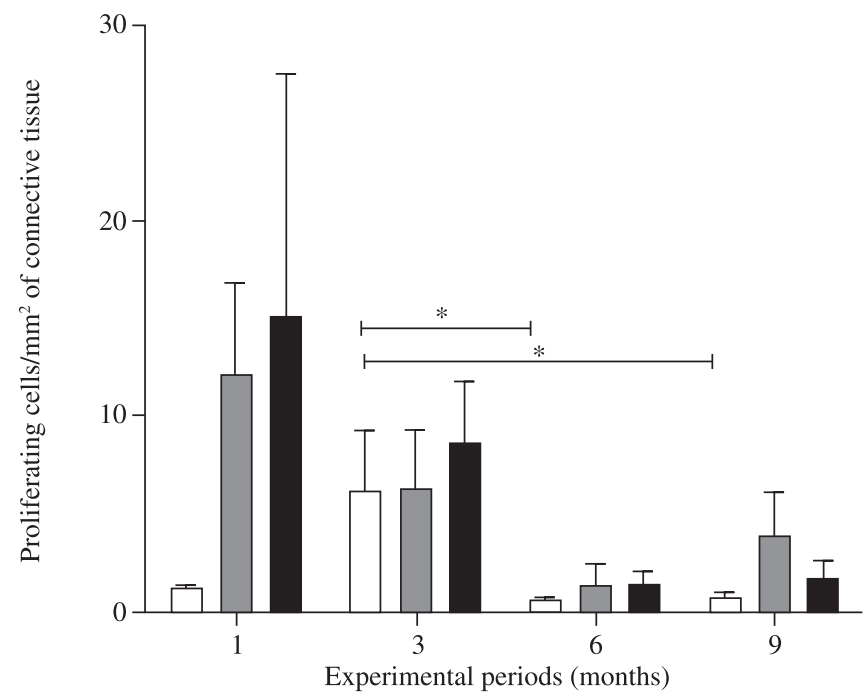

(f)

Groups

Blood clot $\square$ HA-1 $\square$ HA-2

Figure 2. Count of inflammatory cells, microvessels and proliferating cells per $\mathrm{mm}^{2}$ of connective tissue. (a) Polymorphonuclear cells; (b) Mast cells; (c) Macrophages; (d) Foreign body multinucleated giant cells; (e) Microvessels; (f) Proliferating cells. Bars represents mean plus standard deviations of each end-point. Asterisk $(*, p<0.05 ; * *, p<0.01)$ represents significant differences among experimental periods for the same experimental group. Different letters means significant differences $(\mathrm{p}<0.05)$ among groups at the same experimental period. 


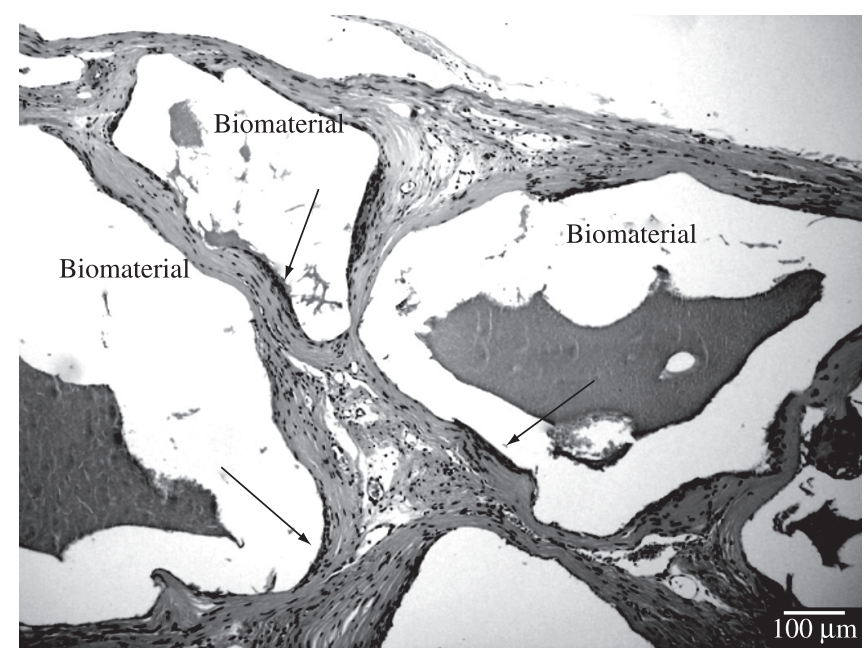

Figure 3. Photomicrograph showing multinucleated foreign body giant cells around HA-2 (arrows) H\&E.

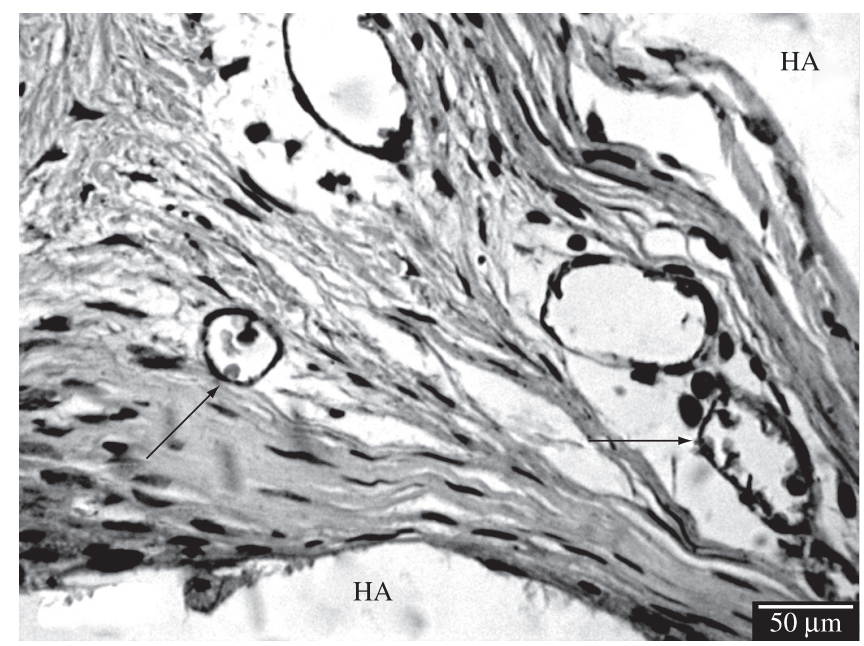

Figure 4. Photomicrograph of anti-Factor VIII immunostained blood vessels (arrows) in the area of implanted HA-2.

contact to particles are also able to produce TNF- $\alpha$ and inflammatory cytokines $^{33}$, inducing osteoblasts to release IL- $6^{34}$.

Angiogenesis is also essential to the proper development of bone because the bone implant requires early vascularization ${ }^{35}$ to provide pluripotent perivascular cells (pericytes) capable of differentiating into osteoblasts $^{36-39}$. The amount of vessels with an inner diameter of less than $50 \mu \mathrm{m}$ indicates the level of angiogenesis ${ }^{40,41}$. In this work, there were no significant changes in angiogenesis after HA implantation.

Cell proliferation is most intense near the implant, where the morphology of the PCNA-immunostained cells is suggestive of mononuclear inflammatory cells ${ }^{42}$. Near the bone border the cell proliferation is less intense, where the immunostained cells are suggestive of osteoblasts involved in new bone formation ${ }^{11}$. In the control group, the proliferating cells were less numerous than in the groups with biomaterials; also, they were dispersed in the entire defect and suggestive of inflammatory cells and fibroblasts. In this group, their increase between months 1 and 3 may be related to tissue repair.
Therefore, hydroxyapatite, is adequate for the filling of alveoli after tooth extraction, allowing preservation of the mucosal contour for the subsequent placement of osteointegrated implants ${ }^{43,44}$, and in elevation of the maxillary sinus regardless of whether it is followed by an implanta$\operatorname{tion}^{45}$, in a manner which is independent of its crystallinity.

\section{Conclusion}

No significant differences in either the quality or quantity of cells in the inflammatory infiltrate between the experimental groups were observed. Also the degree of angiogenesis and cell proliferation was quite similar. We can conclude that HA-1 and HA-2 are biocompatible and that the physico-chemical differences of these biomaterials did not affect cellular response.

\section{Acknowledgements}

The authors thank CNPq, FINEP, FAPERJ and CAPES for their financial support.

\section{References}

1. Granjeiro JM, Taga EM, Fonseca MA, Maeda L, Taga MSL, Trebacchetti CR. et al. Hidroxiapatita para uso clínico: caracterização físico-química. Revista Gaúcha de Odontologia. 1992; 40(2):130-134.

2. Marins LV, Cestari TM, Sottovia AD, Granjeiro JM, Taga R. Radiographic and histological study of perennial bone defect repair in rat calvaria after treatment with blocks of porous bovine organic graft material. Journal of Applied Oral Scince. 2004; 12(1):62-69.

3. Zambuzzi WF, Oliveira RC, Pereira FL, Cestari TM, Taga R, Granjeiro JM. Rat subcutaneous tissue response to macrogranular porous anorganic bovine bone graft. Brazilian Dental Journal. 2006; 17(4):274-278.

4. Zambuzzi WF, Silva TL, Oliveira RC, Granjeiro JM. Avaliação bioquímica de xenoimplantes em subcutâneo de rato. Ciencia Odontológica Brasileira. 2006; 9(4):44-51.

5. Aoki H. Medical applications of hydroxyapatite. 1 ed. Tokyo: Takayama Press System Center Co.; 1994.

6. Fulmer MT, Ison IC, Hankermayer CR, Constantz BR, Ross J. Measurements of the solubilities and dissolution rates of several hydroxyapatites. Biomaterials. 2002; 23(3):751-755.

7. Morgan J, Holtman KR, Keller JC, Stanford CM. In vitro mineralization and implant calcium phosphate-hydroxyapatite crystallinity. Implant Dentistry. 1996; 5(4):264-271.

8. Lorini G, Specchia N, Mannarini M, Rizzi L, Lisai P. The action of loads on bone tissue. Archivio "Putti" di chirurgia degli organi di movimento. 1991; 39(2):249-272.

9. Yang Y, Dennison D, Ong JL. Protein adsorption and osteoblast precursor cell attachment to hydroxyapatite of different crystallinities. International Journal of Oral and Maxillofacial Implants. 2005; 20(2):187-192.

10. Chou L, Marek B, Wagner WR. Effects of hydroxyapatite coating crystallinity on biosolubility, cell attachment efficiency and proliferation in vitro. Biomaterials. 1999; 20(10):977-985.

11. Conz MB. Análise histomorfométrica do reparo de defeito crítico na calvária de ratos tratados com grânulos de hidroxiapatita com diferentes características físico-químicas. [Tese] Rio de Janeiro. Universidade Federal do Rio de Janeiro. COPPE; 2006.

12. Norton MR, Odell EW, Thompson IDE, Cook R. Efficacy of bovine bone mineral for alveolar augmentation: a human histologic study. Clinical Oral Implant Research. 2003; 14(6):775-783.

13. Valentini P, Abensur D, Wenz B, Peltz M, Schenk R. Sinus grafting with porous bone mineral (Bio-Oss) for implant placement: a 5-year study on 15 patients. The International Journal of Periodontics \& Restorative Dentistry. 2000; 20(3):245-253.

14. Anderson JM. Multinucleated giant cells. Current opinion in hematology. 2000; 7(1):40-47. 
15. Anderson JM. Biological responses to materials. Annual Review of Materials Research. 2001; 31:81-110.

16. Gretzer C, Emanuelsson L, Liljensten E, Thomsen P. The inflammatory cell influx and cytokines changes during transition from acute inflammation to fibrous repair around implanted materials. Journal of biomaterials science. Polymer edition. 2006; 17(6):669-687.

17. Luttikhuizen DT, Harmse MC, Van Luyn MJ. Cellular and molecular dynamics in the foreign body reaction. Tissue engineering. 2006; 12(7):1955-1970.

18. Zdolsek J, Eaton JW, Tang L. Histamine release and fibrinogen adsorption mediate acute inflammatory responses to biomaterial implants in humans. Journal of translational medicine. 2007; 5(31):1-6.

19. Misch CE. Implantes dentários contemporâneos. 2 ed. São Paulo: Ed. Santos; 2006.

20. Freitas TMC, Miguel MCC, Silveira EJD, Freitas RA, Galvão HC. Assessment of angiogenic markers in oral hemangiomas and pyogenic granulomas. Experimental and molecular pathology. 2005; 79(1):79-85.

21. Muramatsu K, Bishop AT. Cell repopulation in vascularized bone grafts. Journal of orthopaedic research. 2002; 20(4):772-788.

22. Anderson JM, Rodriguez A, Chang DT. Foreign body reaction to biomaterials. Seminars in Immunology. 2008; 20(2):86-100.

23. Craelius W. The bionic man: restoring mobility. Science. 2002; 295(5557):1018-1021

24. Laurencin C, Khan Y, El-Amim SF. Bone graft substitutes. Expert review of medical devices. 2006; 3(1):49-57.

25. Meijndert L, Raghoebar GM, Schüpbach P, Meijer HJ, Vissink A. Bone quality at the implant site after reconstruction of a local defect of the maxillary anterior ridge with chin bone or deproteinised cancellous bovine bone. Internationa Journal of Oral and Maxillofacial Surgery. 2005; 34(8):877-884.

26. Stal S, Tjelmeland K, Hicks J, Bhatia N, Eppley B, Hollier M. Compartmentalized bone regeneration of cranial defects with biodegradable barriers: An animal model. Journal of Craniofacial Surgery. 2001; 12(1):41-47.

27. Taga, ML, Granjeiro, JM, Cestari, TM, Taga, R. Healing of critical-size cranial defects in guinea pigs using a bovine bone-derived resorbable membrane. The International journal of oral \& maxillofacial implants. 2008; 23(3):427-36.

28. Urist MR, Huo YK, Brwnell AG, Hohl WM, Buyske J, Lietze A. et al. Purification of bovine bone morphogenetic protein by hydroxyapatite chromatography. Proceedings of the National Academy of Sciences of the United States of America 1984; 81(2):371-375.
29. Tang L, Jennings TA, Eaton JW. Mast cells mediate acute inflammatory responses to implanted biomaterials. Proceedings of the National Academy of Sciences of the United States of America. 1998; 95(15):8841-8846.

30. Ooms EM, Wolke JG, Van der Waerden JP, Jansen JA. Trabecular bone response to injectable calcium phosphate (Ca-P) cement. Journal of Biomedical and Material Research. 2002; 61(1):9-18.

31. Kelly JD, Schneider GB. Morphological and histochemical comparison of the cells elicited by ectopic bone implants and tibial osteoclasts. American Journal of Anatomy. 1991; 192(1):45-54.

32. Koerten HK, Van der Meulen J. Degradation of calcium phosphate ceramics. Journal of Biomedical and Material Research. 1999; 44(1):78-86.

33. Glant TT, Jacobs JJ, Molnár G, Shanbhag AS, Valyon M, Galante JO. Bone resorption activity of particulate-stimulated macrophages. Journal of Biomedical and Material Research. 1993; 8(9):1071-1079.

34. Pioletti DP, Kottelat A. The influence of wear particles in the expression of osteoclastogenesis factors by osteoblasts. Biomaterials. 2004; 25(27):5803-5808.

35. Lindhe J, Karring T, Lang, NP. Tratado de periodontia clínica e implantologia oral. 4 ed. Rio de Janeiro: Ed. Guanabara Koogan; 2005.

36. Gartner LP, Hiatt JL. Atlas colorido de Histologia. 3 ed. Rio de Janeiro: Ed. Guanabara-Koogan; 2002.

37. Guttman D, Stern Y, Shpitzer T, Ulanovski D, Druzd T, Feinmesser R. Expression of MMP-9, TIMP-1, CD-34 and factor-8 as prognostic markers for squamous cell carcinoma of the tongue. Oral Oncology. 2004; 40(8):798-803.

38. Mandarin-de-Lacerda CA. Stereological tools in biomedical research. Anais da Academia Brasileira de Ciências. 2003; 75(4):469-486.

39. Murthi P, Kalionis B, Ghabrial H, Dunlop ME, Smallwood RA, Sewell RB. Kupffer cell function during the erythocytic stage of malaria. Journal of gastroenterology and hepatology. 2006; 21(1 Pt 2):313-318.

40. Norton MR, Odell EW, Thompson IDE, Cook RJ. Efficacy of bovine bone mineral for alveolar augmentation: a human histologic study. Clinical Oral Implant Research. 2003; 14(6):775-783.

41. Bonachela WC, Molo Jr. FA, Taga EM, Granjeiro JM. Manutenção do rebordo alveolar com hidroxiapatita microgranular. Revista Gaúcha de Odontologia. 1992; 40(3):212-214.

42. Wallace SS, Froum SJ, Cho SC, Elian N, Monteiro D, Kim BS, Tarnow DP. Sinus augmentation utilizing inorganic bovine bone (Bio-Oss) with absorbable and nonabsorbable membranes placed over lateral window: histomorphometrics and clinical analyses. The International journal of periodontics \& restorative dentistry 2005; 25(6):551-559. 
